\title{
Research Paper Critical analysis on sale and production : A case of milk and milk products
}

\section{SUMAIRA FAROOQ, JYOTI KACHROO AND NAVEED HAMID}

See end of the paper for authors' affiliations

Correspondence to :

NAVEED HAMID

Division of Agricultural

Economics and Agri-

Business Management,

SKUAST-J, JAMMU

(J\&K) INDIA

Email : bhatnaveedbhat

@ gmail.com

Paper History :

Received : 17.05.2017;

Revised : 13.08.2017;

Accepted : 20.08.2017
ABSTRACT : India is world's largest milk producer, accounting for more than 16 per cent of worlds total milk production and is the world's largest consumer of dairy products. The annual milk production of Jammu and Kashmir was estimated 16.51 lakh tonnes and annual compound growth rate was 2.23 percent in 2014-15. The per capita availability of milk is $302 \mathrm{~g} /$ day and its annual compound growth rate was -4.43 per cent in 2013-14. In every market there exists organised and un organised sectors for the marketing of the milk and dairy products. In the organised and un organised sector, there are two main agencies- the milk vendors and the halwais, who collect milk from cattle breeders and supply it to the consumers at their doorstep. The organised sector dairies like JKMPCL, They collect milk from their collection depots or points and transport it to the milk plants for processing and manufacturing. The present study was carried out on the basis secondary data and assisted by primary input from the JKMPC. The results revealed that the growth rate of production of milk during the year 2013-14 to 2014-15 showed increased trend from 0.98 per cent to 2.23 per cent. The per capita availability of milk during the year 2009-10 was $379 \mathrm{~g} /$ day but in 2012-13 the annual growth rate of per capita availability was 10.23 per cent showed negative trend in growth rate. The compound growth rate was found negligible in every month like, as in the month of September, 2014, the total sales were 178084 and calculated CGR was 0.03 per cent negative and comprised value of Rs.48.23 lakhs but in the month of October 2014, the result showed increase in the sales to 252258 with CGR 0.03 per cent and had value of Rs. 77.91 lakhs which revealed huge growth of sales of pouch milk in Kashmir division. For total value the compound growth rate was found to be highest 0.17 per cent in the month of December, 2014 where as lowest -0.13 per cent in March 2015.

KEY WORDS : JKMPCL, Marketing, Processing, Compound growth rate

How To Cite This PAPer : Farooq, Sumaira, Kachroo, Jyoti and Hamid, Naveed (2017). Critical analysis on sale and production : A case of milk and milk products. Internat. Res. J. Agric. Eco. \& Stat., 8 (2) : 387-392, DOI : 10.15740/HAS/IRJAES/8.2/387-392. 